\title{
Compliance Fiction: Adorno and Horkheimer's 'Culture Industry' Thesis in a Multimedia Age
}

\author{
Sam Caslin
}

In today's multimedia, virtual world, the notion of the culture industry is perhaps more pertinent than ever before. Mass entertainment now spans an increasingly diffuse yet seemingly interspersed array of media forms, including television, film, the Internet and the rise of the DVD box set (with the latter's special features and writer/ producer/actor commentary all adding to the allure of the product). A key aspect of the power that each of these media possess is derived from their ability to immerse the viewer, reader or listener within not only a franchise, but a fantasy world that is, at least on the surface, very different to their own. Thus, we find a very powerful infrastructure that engenders, supports and maintains new types of fan culture, among the sci-fi community for example. Indeed, alongside the increasing organization of certain fan bases has come a plethora of new roles for fans and new ways of displaying loyalty to their chosen franchise. If fandom as a vocation is not new, the digital age has ensured that the charity and passion of fans has certainly reached higher levels of professionalism and technical proficiency than before.

I want to use these developments in interactivity, television franchising and fan-organization in order to explore the limits of and possibilities for Adorno and Horkheimer's ([1944] 1997) seminal work on the culture industry. In doing so, I want to explore some of the criticisms often levelled at their work, as well as at other 'negative' critiques of consumer culture more broadly. I will then proceed to consider the contemporary implications of the culture industry via a case study of a very specific group of fans within the science-fiction community, 'Browncoats'-the collective name given to fans of the short-lived American TV series Firefly (2003) and its spin-off Hollywood film Serenity (2005). The actions and organization of this group are significant, not only because they exemplify the way in which relationships between entertainment producers and fans seem to be changing, but they are also illustrative of the efforts fans are prepared to exert in an attempt to challenge, manipulate and gain power within the culture industry.

When Firefly was cancelled in 2002 after just 14 episodes, the Internet became a haven for fans wanting to express their outrage and ambitions to get the decision overturned. Their hopes for a revival were, in part, answered in 2005 with the release of Universal's 'spin-off' motion picture Serenity, which, whilst satisfying existing Firefly fans' desire to see some of the main plots of the series brought to some resolution, was written so as to be accessible to those unfamiliar with the TV show. Encouraged by this development, fans continued to push for more television series or a film sequel. For example, 'Serenity Day', held on June 23 2006, was a fan-organized, fan-driven event that aimed to increase the profile of the film and thus the series. Most importantly, fans also hoped that the day would prove to entertainment producers that increasing the Firefly/Serenity franchise would be economically rewarding. Thus, the main tactic used in achieving these aims was the mass buying of copies of the film and, where economically possible for the individuals willing to take part, any other Firefly/Serenity merchandise. Fans with spare copies of the DVDs were then advised on Firefly message boards to distribute this surplus amongst friends and family and even to send them to local libraries. Moreover, far from being simply started on the Internet forums of websites such as www.fireflyfans.net (accessed between May 2006-August 2006), the Internet was also a key location in the waging of 
the 'Serenity Day' campaign, with fans urging that copies of Serenity be bought from Amazon.com, which carries its own DVD charts thereby allowing fans to track their campaign's progress during June 23 and afterwards.

The sophisticated organization of such an event, as well as the fans implicit awareness of the interrelatedness of television and the Internet, provides an ideal opportunity to reassess the relevance of Adorno and Horkheimer's ([1944] 1997) culture industry thesis and consider its implications in a multimedia age. Rather than simply bolstering the notion of the culture industry as developed by Adorno and Horkheimer in the mid-twentieth century, it is hoped that this exploration will address the contemporary importance of the culture industry and engage in the kind of empirical critiquing of the culture industry that Adorno (2001:196) very much supported. In particular, then, it is my contention that the tactics used by this group of fans in order to revive a specific television franchise after the series was cancelled can provide a significant insight into the relationship between modern consumerism, the production of cultural artefacts and the importance of Adorno and Horkheimer's culture industry. That is to say that with fans acting voluntarily as marketers and 'guerrilla promoters' for the existing Firefly/Serenity merchandise, not to mention their roles as consumers of that franchise, it is my contention that these fans are actually being absorbed further into the mechanisms of the culture industry with their identities becoming ever more tied to their sense of themselves as fans of Firefly/Serenity. Moreover, in attempting to prolong the life of their product of choice by trying, through the mass purchasing of DVDs and merchandise, to guarantee a market, the actions of the Firefly/Serenity fans suggests an increasing rationalization of consumer culture whereby fans are no longer required to simply consume passively but to become actively involved in the mechanisms of production and market creation. Yet, it does not matter whether or not the producers respond to these types of consumer demand since the consumer has already ensured a profit through the free advertising they volunteer for the product. In this way, the old relations of supply and demand have become more complex: Rather than producers seeking out markets, the consumer now believes that they must actively ensure demand before any supply is considered. As such, the title of this article is not merely an irreverent pun; rather it describes a state of cultural production that sees the consumer aim to tautologically produce and consume products. In short, their compliance with the culture industry is such that their desire for particular products overrules their ability to critique their function. In accordance with Gunster (2000:66-67), I attempt to use this empirically-based case study in order to develop Adorno and Horkheimer's theory of the culture industry and produce an account of new trends, ambiguities and contradictions found in the conflated space between economic and cultural production.

In particular, I want to address whether or not Adorno and Horkheimer's ([1944] 1997:137) suggestion that mass culture requires minimal effort on the part of the consumer is still accurate in light of consumer demands for products such as those discussed in this article. Yet, in dealing with this question, we must first ascertain whether or not consumers are now perhaps more aware of the existence of a culture industry and to what extent they might choose to participate in its processes. Indeed, it is not necessarily the case that Adorno and Horkheimer ([1944] 1997) consider the 'masses' to be unaware of the processes involved in the culture industry. They note: '[t]he triumph of advertising in the culture industry is that consumers feel compelled to buy and use its products even though they see through them' (Adorno and Horkheimer 1997:167). However, this raises an important question: Does this consumer awareness translate into an ability of the 'masses' to make the decision to embrace the culture industry on quite valid personal grounds? That is to say that if consumers are complicit within the culture industry, could it not simply be argued that they are not dominated by it so much as they are willing supporters of this system? In the case of the Firefly/Serenity fans, it is possible that their lobbying for a continuation of the television/movie franchise that they enjoy represents a knowing, deliberate attempt by these consumers to appropriate the production of this product because of the specific meaning it has for them as fans. Moreover, their decision to enact this lobbying by constructing arguments for the rational economic basis for the reinvigoration of the franchise may suggest that these consumers do not hold consumer capitalism in such a negative light as Adorno and Horkheimer, much less agree that they are part of any kind of culture industry.

For the purposes of this article, it could be argued that this notion of the consumer as possessing power or choice is born out by the actions of television fans online, particularly as the internet continues to facilitate the further and more elaborate collectivization of television consumers and their actions. For example, not only do these online consumer fan groups work largely outside the parameters of 'industry control', but their cyberspace presence can also see them accrue significant amounts of online influence as consumers of their television show(s) of choice (Deery 2003:162, 164). In fact, it is argued by Deery (2003:162-164) that TV companies are paying attention to such online activity 'because it is in their economic interest to do so' insofar as an unofficial fan site for a TV show, 
whilst probably not opening the programme up to new audiences, can certainly increase the interest and devotion to a show amongst existing fans, as well as encouraging their consumption of the program's associated merchandise. As such, Deery (2003:167-168) suggests that online fan communities can even have an influence over whether TV shows are prolonged or cancelled, illustrating the increasing interrelationship between producers' decisions with regards to their products and consumers' decisions about what they want to consume (cf. Bacon-Smith's (2000:89) discussion of the importance of online fan communities to the survival of the Babylon 5 TV series). As a result, the relationship between viewers and producers has become a complex, two-way relationship, with both parties negotiating production processes (O’Sullivan 2005:21).

Indeed, if one holds to the notion that the consumer does have some power, then we must address a significant criticism often levelled at the work of Adorno and Horkheimer (as well as similar theories of mass culture): namely, that the notion of the culture industry is elitist in its insistence that social actors are duped into their roles as consumers and in its derogatory approach to mass culture (Kellner 1995:29; cf. Gunster 2000; Miller 2001; Witkin 2003:1). Theories that engage in a negative critique of mass consumer culture stand accused of proffering a narrow moral view of consumption based on particular political and structuralist understandings of the social order and social action. This 'moral' posturing has been roundly critiqued by writers such as Daniel Miller (2001) and Richard Wilk (2001). For Miller (2001:226), the field of consumption is all too often used as a vehicle for academics to pursue their own moral (and, indeed, political) agendas rather than as an empirical area of study that might challenge any such preconceptions. Accordingly, he argues that it is hypocritical of academics to posit a notion of consumption as being an inherently negative act whilst at the same time enjoying the benefits of a consumer society. Moreover, he continues his explication of this double standard by arguing that when large numbers of individuals across the world lack, for example, housing, computers or transport, the idea that commodities represent vacuous excess cannot be justified (Miller, 2001:228). Indeed, it is Miller's (2001:229) contention that 'moralist' theories of consumer society do not take full account of the complexity involved in the individual's consumption habits, with certain commodities having much more complex roles and meanings than such theories allow. Moreover, Miller (2001:229230) extends this argument further when he suggests that even those goods with less obviously utilitarian values should be approached "respectfully" because of their potential symbolic significance.

Wilk (2001) is similarly critical of negative theories of mass consumer society. He positions the academic who is critical of consumerism as a self-appointed moral guardian whose output sets the parameters of the moral debates that surround mass consumption (Wilk 2001:254). As such, academics are conceived of as an integral part of the consumer culture that they critique; urging caution against excessive consumption, their critiques even seem to be appropriated by and given a sanctioned role within mass culture. In a world of temptation, the academic's criticism only serves to fuel self-restraint and order during periods of work. Moreover, Wilk (2001:251) proposes that reliance upon the notion of false consciousness in order to explain consumption as a part of mass culture erroneously elevates the theorist to a privileged vantage point whereby they are able to see the reality behind mass culture whilst the masses are not (cf. Miller 2001:229). At the same time, it might also be added that theories of false consciousness almost foreclose any opportunity for their proposition to be challenged. For example, Adorno and Horkheimer ([1944] 1997:145) suggest that any opposition to the culture industry simply represents a resistance infused within the system. For Gunster (2000:63), this sanctioned resistance provides a 'veneer of meaning' insofar as it suggests a comforting depth to the shallowness of mass culture, thus placating any serious discontent. In this way, any attempt to refute Adorno and Horkheimer's culture industry thesis can be automatically dismissed as an act of the system itself.

However, if we look specifically at the notion of the culture industry, I would argue that Adorno and Horkheimer ([1944] 1997) manage to avoid taking the moral position that all commodities are necessarily bad or that consumption must therefore be castigated as wrong. Rather than targeting all commodities per se, the culture industry thesis critiques a specific type of gentrified, mass-produced artefact aimed at legitimating capitalism (Kellner 1995:28-29). As such, it is not the case that the culture industry thesis requires that all commodities be considered vacuous. Instead, it suggests that there is a particular type of cultural commodity that has been colonized by capitalism insofar as it has little use value, differs only insignificantly from other products and is, despite all of this, revered by consumers. This reverence is therefore derived from the product's exchange value (cf. Gunster 2000:50). In this way, the notion of commodification critiqued by the culture industry differs from Miller's (2001) broader deployment of the term 'commodity' as something that is a part of material culture. Adorno and Horkheimer's theory leaves enough room to suggest that what is critiqued by the culture industry is not the idea of the 'commodity' in the broadest possible 
definition of the word (and thus not those goods required most by those in situations of poverty, such as housing and clothing), but the notion of a commodity where its use value has been completely usurped by exchange value. The objection, then, is not so much to the commodities themselves but the state of mass consumption whereby 'the culture industry transfers the profit motive naked onto cultural forms' (Adorno 2001:99).

Moreover, Adorno and Horkheimer's work signifies that we should not overestimate the extent to which consumers have a choice about what they consume or how and where they consume. Such are the totalizing effects of brand recognition that Adorno (2001:85) goes as far as to argue that advertising has become a form of 'information'. Indeed, Bauman (2005:26) echoes this position when he argues that despite all their power to choose between different products, brands and logos, what consumers actually lack is the power to decide not to choose between these things. To a large extent at least, consumer power/choice is therefore illusory. Even when consumers are apparently successful in evading control or achieving their aims, their power is always in subservience to capitalist modes of production. Consequently, the consumer's success only further cements their role in consumer society: in other words, although consumers may have some power within consumer society this only negates the potential for them to have power over consumer society. Modes of production cannot be controlled or challenged from within.

To return to the supposed power of television consumers specifically, Deery (2003:180) has argued that the television set will be used as an increasingly invasive device in order to accrue ever more information about the lives of individuals, commodifying the lives of viewers. As a consequence, we are left with Adorno's notion of 'pseudorealism' and its proposition that there is now a conflation of reality and ideology which hinders the consumer's capacity for critique (Witkin 2003:139). It is not the case that the culture industry conceals the reality of the social order from social actors, but rather that it makes it difficult for social actors to envisage any alternative social order (Gunster 2000:44). According to the culture industry thesis, then, it is ironic that the films and novels of popular culture could be considered escapist, since they actually serve to draw closer the imagined world of entertainment and the real world (Gunster 2000:43-44). Indeed, it is my contention that, as the Internet becomes more and more integrated into the everyday actions of those in the West, this process of 'pseudo-realism' is even more pertinent. Not only does fan activity on the Internet obfuscate the distinctions between different forms of media, for example with television and the internet now serving the same consumer groups with the same products, but it also produces a conflation between the virtual world and the real one. At the same time as a television programme is being broadcast, fans can also go online and visit both official and unofficial websites in order to download pictures, information or future episodes of said program. The chat rooms and message boards utilised by entertainment fans perhaps represent the pinnacle of this 'pseudo-realism' since they allow social interaction to take place on a new virtual plane where the needs for proximity or audio-visual and even temporal links between persons are removed.

Thus I take Deery's argument further: not only are viewers' private habits turned into markets for consumption, but the viewers themselves, knowingly or unknowingly, actually become key players in that transformation through their participation in online TV-fan communities. Though it may seem that these consumers have the potential to wield significant power over TV stations, they are instead being converted into cogs within the production process, meaning that they run the risk of becoming exploited on ever more sophisticated levels. Bacon-Smith (2000) notes that official websites for science fiction television shows can in fact be exploitative of fan-bases, with product promotion being an integral part of such sites' raison d'etre (p.87). Moreover, there is also a potential tension between what fans want to post on the internet and what they perceive themselves to be allowed (by corporate powers) to post, as is illustrated by the case of www.spoilerslayer.com (retrieved 5 October 2006), a now inactive website that once provided plot spoilers (information about TV show storylines before they have been broadcast) for TV shows such as Buffy the Vampire Slayer and Angel. Closed on August 21st 2004, the website claims to have experienced legal issues with regards to making future storylines available. On hearing of the suspension of activities on www. spoilerslayer.com, a fan expressed on whedonesque.com, a website dedicated to Joss Whedon (the creator of the aforementioned programs and Firefly), 'it is sad to see another example of overpaid Hollywood bullies trying to write the rules of the internet to suit their bottom line' (Herb 2004). Another also responded, '...it contributes to my anger at these Goliaths who seem to think we fans have no memory, that we are only wallets with legs' (Palehorse 2004). Yet this dismay at the events surrounding The Spoiler Slayer was not unanimous. A fan commented, 'Joss has said time and again that spoilers have plagued him. The only sad thing about this news is that it didn't happen years ago' (MindPieces 2004). One respondent sardonically criticized a fan's decision to boycott the television station by asking:

Um, you do realize that BtVS [Buffy] and ANGEL are "Fox" products? (Since they were produced by Twentieth Century Fox.) And Firefly was too, until the rights were sold to Universal. SaveAngel (2004) 
The differing opinions expressed here suggest that fans, whether critical or supportive of the rights of producers, are nevertheless aware of the concerns that producers may have about the way in which fans' online interactions may influence the market success of their product. It follows then that fans of television believe themselves to have an important role to play in the production of their television programs of choice. Moreover, the following discussion of the Firefly/Serenity campaign will illustrate that such fans are only too keen to exert their 'influence' on producers. However, whether fans can be considered to have any real power in this relationship, other than that which is derived through their loyalty as an audience, is doubtful.

\section{| Consumer Power or 'Misguided Spontaneity' (Adorno 2001:194)}

Pleasure hardens into boredom because, if it is to remain pleasure, it must not demand any effort... -Adorno and Horkheimer ([1944] 1997:137)

When I first signed on to do this and help organize, I never thought this would be such a huge movement. I am constantly amazed by the spirit and generosity of Browncoats. For a fangroup that relies heavily on word-of-mouth we accomplish alot [sic] more than some people realize. Once again we are doing the impossible. -Kaele (2006), message board, www.fireflyfans.net

The two quotes above have been selected because of the way in which they neatly juxtapose one another. The first suggests that under the rule of the culture industry, pleasure cannot be about anything other than stagnation on the part of the audience. The standardization of cultural forms is such that the consuming of products requires no extra interpretation on part of the individual (Adorno and Horkheimer [1944] 1997:137). In his later work, Adorno (2001) develops this further and associates boredom with a state of unfreedom, whereby 'shallow entertainment' and cultural stasis provide consumers with the will to work (p. 193). Leisure, then, has been divorced from work insofar as it is accepted that one's free time must differ from work activities so as to ensure a productive work realm (Adorno 2001:190). For Adorno (2001: 188, 193), free time is thus 'becoming a parody of itself', with individuals increasingly devoting their time to 'superfluous' hobbies that produce 'superfluous' products. At the same time, individuals are said to engage in 'pseudo-activity' inasmuch as they immerse themselves in 'spurious' activities in order to distract from the realization that changing the social order would be exceptionally difficult (Adorno 2001: 194).

This later note stands in stark contrast to the opinions expressed in the quote above by Kaele, a Firefly/Serenity fan writing online about 'Serenity Day', an event organized by fans of the franchise in order to convince television stations and film studios that investment in the continuation of the series would result in a marketable product and guaranteed financial rewards. Far from requiring minimal effort, then, 'Serenity Day' represents a serious drive on behalf of a large section of a fan-base. Requiring collective organization in terms of both tactics and objectives, it could be argued that the actions of those fans seeking to revive this particular franchise is indicative of something more than consumer boredom and apathy. In some ways it could even be seen as a revolt against this. For example, when interviewed for an unofficial documentary entitled Done the Impossible: The Fans' Tale of Firefly and Serenity (2005), one fan suggested that the cancellation of Firefly 'was maybe a lightning rod for our frustration with television and pretty much, you know, pop culture in general, kind of appealing to the lowest common denominator.' Boredom, it seems, was what those opposed to the cancellation were fighting. Indeed, the very media through which these views were aired, an unofficial DVD documentary containing 'special features' such as a 'Trivia Game' and featuring interviews with fans, cast members and behind-the-scenes production staff, all suggests a high degree of activity amongst Firefly/Serenity fans. In addition, Firefly/Serenity fans' awareness of their economic position permeating the production-consumption chain is not without a social conscience. Rather than just advocating the mass purchasing of DVDs on 'Serenity Day', the actions of fans were also put to charitable use with a portion of the profits from special local screenings of Serenity and from sales of the documentary Done the Impossible: The Fans' Tale of Firefly and Serenity going to the charity Equality Now, of which Joss Whedon, creator of Firefly and Serenity, is a supporter.

For these fans, the consumption of television is not simply about passively receiving homogenized and uninspiring cultural products (cf. Adorno and Horkheimer [1944] 1997), instead it also involves the viewer's participation in the realms of production. The role of viewer is transformed from its receptive state into a proactive position whereby fans, in their desire to continue consuming particular programs, are willing to embrace their status as a 'market.' 
Thus, in a discussion on www.serenityday.org on June 12 2006, one fan answered a fellow fan's question about where DVD's should be purchased from on Serenity Day:

I don't think it should matter. We're trying to send a message to Universal, not Amazon or other retailers. Universal will see how many people buy copies of their movie reguardless [sic] of what version it is, so as far as I know, any version you buy should count. thegrimfandango (2006)

Yet, on June 13 2006, another fan responded to the same discussion with,

I think we should all buy through Amazon.com. Its [sic] one of the main online websites and it gets a ton of attention in the entertainment industry-people at the movie studios DO look at Amazon to see whats [sic] hot and whats [sic] not. Also, if we buy through brick-and-morter [sic] stores, the studio will only see the numbers go up if the store owners order more copies. longbowhunter (2006)

Following 'Serenity Day' such debates did not cease, indicating that, despite Firefly being cancelled in 2002, this is very much an ongoing campaign. On 1 August 2006, one fan visited the message boards of www.fireflyfans.net and posted a list of instructions for those intending to email executives with regards to restarting the franchise. One instruction contained the advice: 'In show business, the biggest issue is $\$ \$ \$ \$$, so we have to show the executives how much money they could make if Firefly was in their lineup [sic], and how much they are missing by not having it there' (LORDKILBORN 2006). Discussions such as this illustrate the extent to which fans involved in trying to reinvigorate the Firefly/Serenity franchise understand the nature of the campaign to be economic. Accordingly, they attempt to play the system to their own advantage. Yet does this attempt at manipulating the system rather than changing it support the aforementioned notion of 'pseudo-activity' as outlined by Adorno (2001:194)? Are these fans simply repressing the fact that to change the system would be harder than to attempt to play it by its own rules?

According to Adorno and Horkheimer ([1944] 1997:121), under the conditions of the culture industry, monopolies are no longer concealed by those who run them; instead, an ideology of business abounds whereby industries no longer have to pretend that what they produce represents any kind of art. This notion is clearly reflected in the opinions and frustrations of some fans on the website www.fireflyfans.net, with one explaining that the instrumental, economic drives of studios results in 'Nothing new here, nothing new to say, just the same vapid entertainment quality' (HERA 2006). Yet, despite this perceived blatancy surrounding the self-serving blandness of the culture industry, Adorno and Horkheimer ([1944] 1997:121-122) significantly suggest that its power nevertheless grows, with consumers' attitudes forming a 'part of the system' rather than constituting an explanation for it. Thus, these fans are not claiming power in the culture industry; instead they are being dominated by it. Firefly/Serenity fans' recognition of their economic potential and their belief that as consumers united to form a 'market' they have a power within the culture industry, only serves to increase their potential for exploitation. In this way, the guerrilla marketing tactics employed by this group can be seen to represent the sort of 'pseudo-activity' that Adorno critiqued. Moreover, the distinction between work and leisure that Adorno (2001:189) argues has become a 'norm' under the culture industry perhaps explains why Firefly/Serenity fans are so willing to devote their time to regaining this product rather than simply moving their affections on to some new form of entertainment. As one fan suggests:

We have a 10 hour day at work...We have an hour commute in, an hour commute out. We have a half-hour lunch inside. We try to sleep eight hours; that never happens...You come home and you do supper; you take care of homework with children and then all of a sudden you find yourself with an hour or two of time to look...at some TV and get some entertainment and let go of the day. And we choose that time carefully. So it was a big loss to us, entertainment-wise, when we heard it was going to be cancelled. Done the Impossible: The Fans' Tale of Firefly and Serenity.

For this fan, the Firefly/Serenity franchise is not something that he idly gives himself to. It is important to note that contrary to Adorno's (2001:193) suggestion, this man is not interested in 'shallow entertainment'; rather he sees himself as carefully selecting that which he chooses to watch. That his free time is so scarce means that whatever he chooses to do with it automatically assumes great meaning for him because he has deemed it worthy of his attention.

The lengths to which these fans are prepared to go means that it would be trite to suggest that they are simply chasing a vacuous product of the culture industry, a product that has a much higher exchange value than it does a use value. For these fans, the symbolic importance of the Firefly/Serenity product in their daily lives is highly significant and, in this way, it could be argued that the franchise possesses tremendous symbolic use value for its fans. In appropriating the name 'browncoats', the name adopted by those members of the fictitious crew who fought in a war against interplanetary unification, the fans have created for themselves an almost militaristic identity, whereby 
their battle to have the Firefly/Serenity stories continued parallels the battles of their heroes, with self-styled rebel hero fans fighting against the might of capitalist TV stations and film studios. However, what cannot be denied is that their devotion goes beyond the creation of a collective fan identity; these fans also exhibit an economic devotion to the programme. Firefly was not just a TV program. For those financially involved in its development, distribution and marketing it was a commodity - the DVD box set alone ensured this. Moreover, since the release of the film even more merchandise has become available, from posters to trading cards and action figures. For this group of people, the value of this product is two-fold. On the one hand, the franchise is considered by fans to have an important role within their lives as a form of entertainment and identity. Yet, on the other hand, it is recognized that Firefly/ Serenity is an economically governed and profit-driven product. The existence of a franchise of Firefly/Serenity products indicates that, for fans, being economically involved in the package is an important part of the way in which the product is engaged with and thus given meaning. In this way, the product has both a use value (in terms of the meaning it holds for individual fans) and an exchange value.

The problem with this, however, is that the product's use value and exchange value are interlinked, with fans experiences of the product being consciously played out and negotiated against the product's need to be economically successful. Products can have meaning within the culture industry and it is acknowledged that people do have often personal and emotional attachments and uses for that which they buy. However, it is this sense of attachment to particular products that prevents them from making any real challenge to the overall power of the culture industry. In the case of the Firefly/Serenity fans, questions about the power of producers and the subordination of cultural products to capitalist profit-motives is ultimately lost amid their desire to have their product, their characters and their stories returned to them.

The mass purchasing of DVDs and guerrilla flyering represent just two of the ways in which the case study fans discussed in this article have attempted to gain some power within the mechanisms of modern cultural production and Western consumer society as a whole. What this shows is that the culture industry is no longer about the passivity of the audience. Rather the culture industry, because of new opportunities for fan organisation such as that provided by the internet, is able to inculcate fans into assembling themselves into markets. The fans of Firefly/Serenity are not alone in turning to the Internet to show their devotion to a product. Online fan petitions are a common way for fans to protest at the cancellation of TV shows and demonstrate the size and devotion of the fan base at the same time. For example, at the time of writing, fans of Supernatural, an American TV show facing cancellation, have compiled an online petition, 'SAVE SUPERNATURAL !!!!! Petition,' in a bid for more series (www.ipetitions. com, accessed March 30, 2007). Similarly, fans of TV science fiction show Stargate: SG1 set up an online petition protesting at a decision not to let a video game, Stargate SG1: The Alliance, be made. In comments addressed to the program's makers (MGM), the petition stated: 'We, the Stargate Community, the people who allowed the Stargate Franchise to prosper are outraged' (www.petitiononline.com, accessed March 30 2007). In this latter case, fans are not only aware of their importance to the success of the franchise but are actually calling for its expansion into a new format of entertainment. Interestingly, this petition also coincided with other online fan action attempting to revive the recently cancelled Stargate: SG1 TV show itself. Deploying tactics identical to that of the Firefly/Serenity campaign, one Stargate: SG1 website urged fans to 'Make October 3rd [2006] Stargate Day' by purchasing the DVD Box Set of Series 9 on October 3 (its release date). The website also provides a link to the Amazon.com website and the message 'leave no one in doubt of the financial clout and commitment of Stargate SG-1's fans!' (savestargatesg1. com, September 26 2006, retrieved March 30, 2007).

As yet, the Firefly/Serenity fans battle for a continuation of the franchise has not been successful and many online petitions will not yield the desired result for fans of particular products. Thus, by believing themselves to have a role to play in production, and unless the true producers decide otherwise, the actions of these fans serve only to promote that which has already been made. For example, one fan responded to recent news of plans for a 'special edition' DVD of Serenity (a re-release with extra special features) with the comment 'I expect I'll buy it no matter what the features are' (jam2, 2007). Another sarcastically noted 'talk about taking advantage of the loyal fans' before going on to write '[s]eriously, though, I yelped so loud at this news I set off the car alarms in the parking lot' (Dizzy 2007). With fans engaging with television programs in this way, the potential for them to be exploited by the culture industry increases. That is to say that rather than asking important questions about the way in which cultural products are held in subservience to market forces, fans do engage in 'pseudo-activities' (Adorno 2001:194) such as trying to prove the economic worth of a single product. In trying to intervene in and manipulate market forces in order to play the capitalist system to their own advantage fans instead play into the culture industry's hands. 
In this way, we see that Adorno and Horkheimer's notion of the culture industry is still highly relevant to our understanding of consumer capitalism, not least because consumers still venerate the symbolic aspects of products rather than asking important questions about their use value and how they are produced. As capitalism has continued to evolve into what many have termed a 'postmodern' age, Adorno and Horkheimer's work has thus retained its function as a seminal critique of the social order. However, it is important to note that the exceptionally proactive attitudes of the fans discussed in this article do indicate the need for a rearticulation (as opposed to a more dramatic revision) of certain aspects of the culture industry thesis. Fans do feel very strongly about the franchises that they support and, as multimedia capitalism continues to diversify in ever more sophisticated ways, the consumer's role is not as passive as it first appears in Dialectic of Enlightenment ([1944] 1997:137). The fan in particular now has multiple roles to play, from consumer to advertiser and, if their own desires are fulfilled, producer. To point this out is not a complete departure from the critical theory of Adorno and Horkheimer insofar as this surge of consumer activity is highlighted and explained by Adorno's (2001:194) own discussion of 'misguided spontaneity' and 'psuedoactivity'. What this article seeks to highlight is the ever increasing role that these types of activities play in the multimedia age. As such, these aspects of the culture industry thesis need to be emphasised and incorporated into new critical discourses in light of contemporary developments within capitalism. Moreover, as capitalism and the role of the consumer within the culture industry evolves, we need to continually reassess the work of Adorno and Horkheimer, consider its relevance to contemporary economic and cultural climates and promote the importance of cultural critiques of consumption in the multimedia age.

It is hoped that by revisiting such works, new questions and considerations might be raised about the changing aspects of the capitalist system and that the legacy of critical theory will be usefully continued.

\section{References}

Adorno, Theodor W. 2001. The Culture Industry: Selected Essays on Mass Culture. London: Routledge.

Adorno, Theodor W. and Max Horkheimer. [1944] 1997. Dialectic of Enlightenment. London: Verso.

Bacon-Smith, Camille. 2000. Science Fiction Culture. Philadelphia: University of Pennsylvania Press.

Bauman, Zygmunt. 2005. Work, Consumerism and the New Poor. Maidenhead: Open University Press.

Deery, June. 2003. “TV.com: Participatory Viewing on the Web." The Journal of Popular Culture 37(2):161-183.

Dizzy. 2007. 'Whedonesque: Comments on 12606-Serenity Special Edition DVD to be released in July', whedonesque. com, March 1 2007. Retrieved March 25, 2007 (http://whedonesque.com/comments/12606). Fireflyfans. Retrieved May 2006-August 2006 (http://www.fireflyfans.net).

Gunster, Shane. 2000. "Revisiting the Culture Industry Thesis: Mass Culture and the Commodity Form." Cultural Critique 45:40-70. jam2. 2007. "Whedonesque: Comments on 12606: Serenity Special Edition DVD to be released in July", whedonesque.com, March 1 2007. Retrieved March 25, 2007 (http:// whedonesque.com/comments/12606).

Hancock, Tony, Jason Heppler, Jeremy Neish, Jared Nelson, and Brian Wiser. 2006. "Done the Impossible: The Fans' Tale of Firefly and Serenity Done the Impossible."

HERA. 2006. (http://www.fireflyfans.net). July 27 2006, message board. Retrieved July 27, 2006 (http://www.fireflyfans.net/ thread.asp? $b=2 \& t=22605$ ).

Herb. 2004. 'Whedonesque: Comments on 4726: Spoiler Slayer Retires', whedonesque.com, 22nd August 2004. Retrieved August 25, 2006 (http://whedonesque.com/comments4726).

Kaele. 2006. (http://www.fireflyfans.net). June 23, 2006 , message board, www.fireflyfans.net/thread.asp?b=2\&t=21699 Retrieved June 23, 2006.
Kellner, Douglas. 1995. Media Culture: Cultural Studies, Identity and Politics between the Modern and the Postmodern. London: Routledge.

Longbowhunter. 2006. www.serenityday.org, June 132006 , message board. Retrieved June 23, 2006 (http://forum.serenityday.org/viewtopic.php?t=69). Retrieved June 23, 2006.

LORDKILBORN. 2006. www.fireflyfans.net, 1st August 2006, message board, www.fireflyfans.net/thread.asp? $\mathrm{b}=2 \& \mathrm{t}=22734$ [1st August 2006].

Miller, Daniel. 2001. “The Poverty of Morality." Journal of Consumer Culture 1(2):225-243.

MindPieces. 2004. "Whedonesque: Comments on 4726: Spoiler Slayer Retires.” whedonesque.com, 22nd August 2004. Retrieved August 25, 2006 (http://whedonesque.com/ comments4726).

O’Sullivan, Tim. 2005. “From Television Lifestyle to Lifestyle Television.” In Ordinary Lifestyles: Popular Media, Consumption and Taste, edited by David Bell and Joanne Hollows. Maidenhead: Open University Press.

Palehorse. 2004. "Whedonesque: Comments on 4726: Spoiler Slayer Retires”, whedonesque.com, 22nd August 2004. Retrieved August 25, 2006 (http://whedonesque.com/ comments4726).

SaveAngel. 2004. "Whedonesque: Comments on 4726: Spoiler Slayer Retires", whedonesque.com, 22nd August 2004. Retrieved August 25, 2006 (http://whedonesque.com/ comments4726).

Savestargatesg1.com (26th September 2006) "Supporting Stargate: Blog Archive: The Future of SG-1: TV Movies?" Retrieved March 30, 2007 (http://savestargatesg1.com/ news/?p=345).

"Save "Stargate Sg1: The Alliance" Petition." Retrieved March 30, 2007(http://www.petitiononline.com/SGTA/petition.html). 
"SAVE SUPERNATURAL !!!!! Petition." Retrieved March 30, Whedon, Joss. 2003. Firefly. [DVD] 20th Century Fox Home 2007 (http://www.ipetitions.com/petition/savesupernatural/).

Serenity Day. Retrieved June 2006 (http://www.serenityday.org).

Thegrimfandango. 2006. (http://www.serenityday.org). 12th

June 2006, message board. Retrieved June 23, 2006(http:// forum.serenityday.org/viewtopic.php?t=69).

The Spoiler Slayer. Retrieved October 5, 2006.(http://www.spoilerslayer.com).

Entertainment.

Whedon, Joss. 2005. Serenity. [DVD] Universal Pictures Video. Wilk, Richard. 2001. "Consuming Morality." Journal of Consumer Culture 1(2):245-260.

Witkin, Robert W. 2003. Adorno on Popular Culture. London: Routledge. 
